\title{
CZYNNIKI WPŁYWAJĄCE NA ROZLICZENIE KRAJOWYCH TRANSAKCJI W PODATKU OD WARTOŚCI DODANEJ W FIRMACH ŚWIADCZĄCYCH USŁUGI TRANSPORTU DROGOWEGO TOWARÓW
}

\author{
Ewelina Owczarek \\ Wydział Prawa i Administracji \\ Uniwersytet Łódzki
}

\section{Streszczenie}

Niniejszy artykuł został napisany w związku z licznymi problemami podatników z prawidłowym rozliczeniem podatku od wartości dodanej. Problemy te wynikają między innymi z częstych zmian przepisów podatkowych, ciągłym rozwojem branży transportowej w Polsce oraz zwiększającą się z roku na rok ekspansją na rynki zagraniczne.

Celem artykułu jest identyfikacja czynników wpływających na prawidłowość rozliczeń krajowych w podatku od wartości dodanej dla firm transportowych. W publikacji omówiono elementy konstrukcyjne podatku od towarów i usług w Polsce, scharakteryzowano specyfikę rozliczeń krajowych w VAT dla firm transportowych, a także przedstawiono procedurę rozliczeń krajowych w podatku od wartości dodanej na przykładzie Firmy Transportowej XXX.

Badania zostały przeprowadzone na podstawie stosownej dokumentacji wszelkich transakcji opodatkowanych VAT, które zaszły w wyżej wymienionej firmie w miesiącu marcu 2017 r. Przeprowadzone badania wykazały mnogość czynników wpływających na prawidłowe rozliczenie w podatku od towarów i usług, w firmach świadczących usługi transportu krajowego. Ich znajomość i właściwe stosowanie ma bardzo duży wpływ, aby poprawnie rozliczyć się z urzędem skarbowym oraz prowadzić księgi podatkowe zgodnie z przepisami prawa.

Słowa kluczowe: transport, podatek naliczony VAT, podatek należny VAT.

JEL Class: K34.

Artykuł powstał na podstawie niepublikowanej pracy licencjackiej. 


\section{WPROWADZENIE}

Jeden z podatków pośrednich, który opłacany jest przez każdego obywatela - konsumenta nosi nazwę podatku od towarów i usług, zwanym również VAT, czy też podatku od wartości dodanej. Znajomość przepisów krajowych oraz międzynarodowych dotyczących VAT jest konieczna między innymi ze względu na rosnącą z roku na rok globalizację. W dzisiejszych czasach wiele osób decyduje się na założenie własnej działalności gospodarczej. Wzrost zakładanych przedsiębiorstw widoczny jest między innymi w branży transportowej. Przedsiębiorcy z reguły współpracują z innymi krajowymi firmami. Transakcjom krajowym zawieranym na rynku towarów i usług towarzyszy bezwzględnie podatek od wartości dodanej, który powinien być prawidłowo rozliczony przez każdego podatnika do tego zobowiązanego.

Celem pracy jest identyfikacja czynników, które mają wpływ na prawidłowość rozliczeń krajowych w podatku od wartości dodanej dla firm transportowych. W artykule omówiono elementy konstrukcyjne podatku od towarów i usług w Polsce, scharakteryzowano specyfikę rozliczeń krajowych w VAT dla firm transportowych oraz przedstawiono procedurę rozliczeń krajowych w podatku od wartości dodanej na przykładzie Firmy Transportowej XXX. Artykuł kończy dokładne wskazanie czynników wpływających na prawidłowe rozliczenie podatku od towarów i usług w przypadku transportu krajowego.

Praca obejmuje stan prawny na dzień 31 marca 2017 roku.

\section{ELEMENTY KONSTRUKCYJNE PODATKU OD WATOŚCI DODANEJ W POLSCE}

Określenie „podatek VAT” pochodzi od angielskiego zestawienia słów Value Added Tax, co w języku polskim oznacza dokładnie: podatek od wartości dodanej. W rzeczywistości spotykamy się również z nazywaniem VAT-u podatkiem od towarów i usług (ang. Goods and Services Tax) [Thuronyi 1996: 4].

Podatek od wartości dodanej stanowi główne źródło dochodów państwa. Po raz pierwszy $w$ Polsce podatek ten został uregulowany prawnie na mocy ustawy z dnia 8 stycznia 1993 r., która w życie weszła z dniem 5 lipca 1993 r. [Dz.U. 1993, nr 11, poz. 50 z późn. zm.]. Przystąpienie do Unii Europejskiej zmusiło polskiego ustawodawcę do dostosowania polskiego prawa podatkowego do prawa UE, w wyniku czego powstała nowa ustawa z dnia 11 marca 2004 o podatku od towarów i usług, zwana dalej ustawą o VAT [Dz.U. 2004, nr 54, poz. 535, z późn. zm.]. Podatek od wartości dodanej jest daniną o pośrednim charakterze, należącym do grupy podatków obrotowych [Olchowicz (red.) 2010: 26-29], który pełni cztery podstawowe funkcje [www3]: fiskalną, regulacyjną, informacyjną oraz stymulacyjną. 
Do zasad, które muszą być bezwzględnie przestrzegane przez państwa członkowskie UE zaliczamy [www2]: powszechność opodatkowania, zachowanie warunków konkurencji, faktyczne opodatkowanie konsumpcji, unikanie podwójnego opodatkowania, neutralność oraz wielofazowość.

Polski ustawodawca w przepisach podatkowych dokładnie określił, jakie działania podlegają opodatkowaniu podatkiem od wartości dodanej. Przedmiotem opodatkowania podatkami istniejącymi w polskim systemie podatkowym nazywamy wszelkie działania dotyczące faktycznych lub prawnych zdarzeń, które skutkują odpowiedzialnością podatnika za powstałe zobowiązania finansowe [Sowa 2014: 140, dostęp: 10.12. 2016]. Dokładny zakres czynności, które opodatkowane są podatkiem od wartości dodanej znajdziemy w art. 5 ustawy o VAT. Zgodnie ze wskazanym przepisem prawnym do czynności opodatkowanych VAT zaliczymy [Art. 5 ust. 1 ustawy z dnia 11 marca 2004 r..., Dz.U. 2004, nr 54, poz. 535, z późn. zm.]: odpłatną dostawę towarów oraz odpłatne świadczenie usług na terytorium kraju, eksport towarów, import towarów na terytorium kraju, wewnątrzwspólnotowe nabycie towarów za wynagrodzeniem na terytorium kraju, a także wewnątrzwspólnotową dostawę towarów.

Regulacje prawne określają również, które podmioty muszą rozliczyć się z VAT. Zakres podmiotowy opodatkowania podatkiem od wartości dodanej został uregulowany w art. 15-17 ustawy o VAT. Wszelkie czynności podlegają opodatkowaniu tylko i wyłącznie wtedy, gdy wykonane zostaną przez podmiot będący jednoczenie ich podatnikiem [Wyrok Naczelnego Sądu Administracyjnego z 24 kwietnia 2007 r., sygn. akt I FSK 603/06], czyli osobę fizyczną, która samodzielnie prowadzi przedsiębiorstwo, a także osobę prawną bądź jednostkę, która osobowości prawnej nie posiada [Art. 15 ust. 1 ustawy z dnia 11 marca 2004 r..., Dz.U. 2004, nr 54, poz. 535, z późn. zm.] (tzw. ogólna klasyfikacja podatników). Szczególna kategoria podatników podatku od towarów i usług została zawarta w art. 16-17 ustawy o VAT.

Ważne w podatku od wartości dodanej jest rozróżnienie istoty VAT naliczonego oraz VAT należnego. Podatkiem VAT należnym nazywamy taki podatek, który widnieje na fakturach własnych, wystawionych na skutek dostaw dóbr bądź świadczenia usług przez dany podmiot gospodarczy. Podatek VAT naliczony, jest to ta część ceny brutto, która została wyodrębniona w oryginalnych dokumentach potwierdzających nabycie dóbr bądź usług przez danego podatnika [Sowa 2014: 148, dostęp: 10.12.2016]. Podatek ten nie jest przychodem dla podmiotu sprzedającego dobro lub usługę.

Bardzo duże znaczenie dla prawidłowego rozliczenia podatku ma moment powstania obowiązku podatkowego, który jest wyznacznikiem terminu zapłaty VAT oraz decyduje o zastosowaniu odpowiedniego kursu walutowego przy przeliczaniu wartości $\mathrm{z}$ faktury wyrażonych $\mathrm{w}$ obcych walutach na polskie złote i na odwrót. Zgodnie z zasadą ogólną, obowiązek podatkowy powstaje w chwili 
dostarczenia towarów bądź wykonania usługi. Dokładne objaśnienia dotyczące zasad ustalania momentu powstania obowiązku podatkowego zawarte są w kolejnych ustępach artykułu 19a ustawy o VAT [Art. 19a ust. 2-12 ustawy z dnia 11 marca 2004 r..., Dz.U. 2004, nr 54, poz. 535, z późn. zm.].

Powstanie stanu prawnego, jakim jest wyznaczenie chwili powstania obowiązku podatkowego jest równoznaczne $\mathrm{z}$ ustaleniem podstawy opodatkowania od danej, podlegającej opodatkowaniu transakcji oraz powstaniem możliwości skorzystania z odliczenia podatku po stronie nabywcy [Krywan 2016c: 24]. Pełna definicja podstawy opodatkowania została przedstawiona przez polskiego ustawodawcę w art. 29a. ustawy o VAT. Zgodnie $\mathrm{z}$ tym przepisem, podstawą opodatkowania nazwiemy to, co jest równowartością zapłaty, którą usługobiorcy, nabywcy czy też inne podmioty przekazały lub przekażą danemu dostawcy dóbr lub usługodawcy z tytułu sprzedaży.

Warunkiem prawidłowego rozliczenia się z VAT jest przeliczenie wartości z faktur wystawionych przez zagranicznych kontrahentów, które wyrażone są w obcej walucie, zgodnie z zasadami uregulowanymi przepisami prawa. Przeliczanie na polskie złote odbywa się na podstawie art. 31a ust.1 ustawy o podatku od towarów i usług [Art. 31a ust. 1 ustawy z dnia 11 marca 2004 r. ..., Dz.U. 2004, nr 54, poz. 535, z późn. zm.]. Ustawodawca określił, że kwota z otrzymanej przez krajowego usługobiorcę faktury powinna zostać przeliczona na polską walutę zgodnie ze średnim kursem walut ogłoszonym przez Narodowy Bank Polski (zwany dalej NBP) na ostatni dzień roboczy, który poprzedza dzień powstania obowiązku podatkowego bądź dzień zapłaty przez usługobiorcę części lub całości należności przed powstaniem obowiązku podatkowego.

Zaraz po ustaleniu podstawy opodatkowania VAT należy ustalić właściwą stawkę VAT, która obejmuje dane dobro lub usługę. Konieczna jest znajomość odpowiednich stawek podatku dla danych towarów lub usług obowiązujących w polskim systemie podatkowym. Stawki obowiązujące w 2017 r. w Polsce uregulowane są $\mathrm{w}$ ustawie o VAT $\mathrm{w}$ art. 41 wraz $\mathrm{z}$ dokładnym określeniem, jakie dobra i usługi każda ze stawek obejmuje. W polskim systemie prawnym występują takie stawki jak: $23 \%, 8 \%, 5 \%, 0 \%$.

Zobowiązanie podatkowe dla podatku od wartości dodanej wylicza się jako różnicę pomiędzy podatkiem należnym a podatkiem naliczonym za dany okres rozliczeniowy, którym jest miesiąc bądź kwartał. Ogólne oraz szczególne zasady odliczania reguluje art. 86 oraz art. 86a ustawy o VAT. Zgodnie z zasadą ogólną, tylko zarejestrowani oraz czynni podatnicy mają prawo do obniżenia wartości podatku należnego o wartość podatku naliczonego. Konieczne jest także, aby VAT naliczony przy zakupie dóbr bądź usług był ściśle związany z czynnościami opodatkowanymi podatkiem od wartości dodanej. Odliczenie za dany okres rozliczeniowy odpowiedniej kwoty podatku naliczonego przysługuje jedynie w oparciu o oryginały otrzymanych faktur i ich duplikatów oraz na podstawie 
dokumentów celnych. Zgodnie z podstawową zasadą odliczenia VAT naliczonego powinno dokonać się w rozliczeniu za okres, w którym powstał obowiązek podatkowy (dotyczący nabycia/importu towarów/usług przez podatnika). Możliwe jest wystąpienie dwóch sytuacji: powstanie dodatniej bądź ujemnej różnicy między podatkiem VAT należnym a naliczonym. W pierwszym przypadku mamy do czynienia z kwotą zobowiązania podatkowego, które musi zostać uiszczone do budżetu państwa. W drugim przypadku zaś powstaje nadwyżka podatku naliczonego i w zależności od preferencji podatnika - nadwyżka ta może zostać przekazana na rachunek podatnika bądź potrącana od podatku należnego w kolejnych okresach [www1].

Bycie podatnikiem podatku od wartości dodanej wiąże się z posiadaniem licznych praw i obowiązków. Wśród obowiązków wymienić można m.in. konieczność rejestracji podatnika oraz ewidencjonowanie i dokumentowanie czynności, które opodatkowane są podatkiem od wartości dodanej. Do praw VAT-owca zaliczyć możemy możliwość odwrotnego obciążenia podatkiem od towarów i usług.

Zarejestrowanie się jako podatnik VAT polega na wypełnieniu i złożeniu deklaracji VAT-R w urzędzie skarbowym. Z chwilą złożenia w urzędzie skarbowym deklaracji VAT-R przedsiębiorca jest określany mianem „podatnika VAT czynnego", zaś przedsiębiorca, który może, ale nie jest zobligowany do rejestracji jest nazywany ,podatnikiem VAT zwolnionym”.

Następnym obowiązkiem, jaki należy do podatników czynnych podatku od wartości dodanej jest prowadzenie ewidencji służących poprawnemu rozliczaniu VAT, a przede wszystkim - ustaleniu wysokości powstałego zobowiązania podatkowego. Służą temu dwa typy rejestrów: rejestr VAT zakupu oraz rejestr VAT sprzedaży [Lanzarowicz, dostęp: 19.12.2016]. Przepisy prawa podatkowego nie określają konkretnych wzorów ewidencji oraz wytycznych co dokładnie powinno się w nich znaleźć [Dyszy 2014: 109]. Podstawowe wytyczne dotyczące ewidencji VAT znajdziemy $w$ art. 109 oraz art. 110 ustawy o VAT. W ewidencjach VAT nie wykazuje się czynności nieopodatkowanych, zwolnionych z opodatkowania podatkiem od wartości dodanej, a także tych czynności, od których prawo do odliczenia VAT naliczonego nie przysługuje [Dyszy 2014].

Kolejnym obowiązkiem podatników VAT jest dokumentowanie transakcji zakupu i sprzedaży dóbr i usług. Z terytorialnego punktu widzenia przepis zawarty w art. 106a ustawy o VAT określa przedmiotowy zakres obowiązku, jakim jest wystawianie faktur. Faktura VAT jest najważniejszym dokumentem. Podatnicy są zobowiązani do wystawiania faktur sprzedaży swoich towarów i usług. Faktury mogą być przekazywane zarówno w formie papierowej, jak i elektronicznej. 
Obowiązkiem podatnika jest także przechowywanie dokumentów (faktur), które są związane z rozliczeniem VAT do czasu, kiedy upłynie termin dezaktualizacji zobowiązania podatkowego.

Ostatnim z obowiązków, które zostało nałożone przez Ministerstwo Finansów na określone przedsiębiorstwa jest wysyłanie drogą elektroniczną tzw. raportów JPK_VAT. Następuje to przy użyciu Jednolitego Pliku Kontrolnego, którym nazywamy zbiór danych o danym podmiocie gospodarczym, występujący w postaci systemu informatycznego. Pozwala on na comiesięczny eksport danych przedsiębiorstwa, umożliwiający administracji szybszą weryfikację podatników, szybsze przeprowadzanie czynności sprawdzających i kontrolnych oraz szybsze potwierdzanie prawidłowości rozliczeń. Struktura JPK_VAT dotyczy ewidencji VAT zakupów i sprzedaży. Obowiązek jej przekazywania dotyczy dużych przedsiębiorców, MSP, a także od 1 stycznia 2018 r. - mikro przedsiębiorców.

Ustawodawca obok licznych obowiązków wskazał również prawa, jakie przysługują polskim podatnikom. Procedura, w której obowiązek rozliczania z podatku od towarów i usług jest przerzucany z sprzedawcy na kupującego, określany jest mianem odwrotnego obciążenia lub Reverse charge. Podatnicy VAT nabywający dobra objęte odwrotnym obciążeniem muszą sami naliczyć podatek od towarów i usług. VAT naliczany jest od wartości, która jest wykazana na fakturze i traktuje się ją jako wartość netto. Wielkość podatku w deklaracji VAT wykazuje się zarówno po stronie sprzedaży, jak i po stronie zakupu. Dzięki temu transakcja ta jest zupełnie neutralna dla nabywcy, pod względem podatku od wartości dodanej [Kostrzycka, dostęp: 14.12.2016].

Podatek od towarów i usług może być rozliczany następującymi metodami [Kostrzycka, dostęp: 14.12.2016]: kasową, kwartalną, miesięczną. Przyporządkowanie danej metody do podmiotu zależne jest od wielkości prowadzonej działalności gospodarczej.

Pierwszy ze sposobów rozliczania VAT, jakim jest metoda kasowa, dostępny jest jedynie dla tzw. „małych podatników”. Zgodnie z przepisem ustawy, obowiązek podatkowy powstaje w dniu uzyskania całości bądź części zapłaty (gdy dokonana jest dostawa dóbr lub usług na rzecz podatnika VAT czynnego) bądź w dniu uzyskania całości bądź części zapłaty, jednak nie później niż 180. dnia od momentu dostarczenia dobra lub usługi (gdy dokonana jest dostawa dóbr lub usług na rzecz podatnika niebędącego podatnikiem VAT czynnym) [Art. 21 ust. 1 ustawy $\mathrm{z}$ dnia 11 marca 2004 r. ..., Dz.U. 2004, nr 54, poz. 535, z późn. zm.]. Podatnikom stosującym metodę kasową przysługuje prawo do odliczenia VAT naliczonego nie wcześniej niż w trakcie rozliczenia za okres, w którym została dokonana przez podatnika zapłata za nabyte dobra i usługi [Art. 86 ust. 10e ustawy z dnia 11 marca 2004 r. ..., Dz.U. 2004, nr 54, poz. 535, z późn. zm.]. 
Decyzja tzw. małych podatników o rozliczaniu się drugim ze sposobów, zwanym metodą kwartalną, nie powoduje modyfikacji ogólnych zasad powstawania obowiązku podatkowego czy też odliczania podatku naliczonego. Wybór tej metody skutkuje koniecznością zapłaty przez podatnika podatku należnego oraz prawem do obniżania tego podatku o VAT naliczony na zasadach ogólnych [Szwęch, dostęp: 16.12.2016]. Obowiązkiem małych podatników, którzy wybrali kwartalną metodę rozliczeń z podatku od towarów i usług jest składanie formularza VAT - 7K do 25. dnia miesiąca, następującego po każdym kolejnym kwartale rozliczeniowym [Szwęch, dostęp: 16.12.2016].

Stosując ostatnią z metod rozliczania z VAT, czyli metodę miesięczną (tzw. rozliczenie na zasadach ogólnych), czynności prowadzące do powstania obowiązku podatkowego są rozliczane w terminach miesięcznych.

Jednym z podstawowych obowiązków podatnika VAT jest składanie deklaracji w zakresie podatku od wartości dodanej. Zawarte są $\mathrm{w}$ nich informacje bardzo istotne dla organów podatkowych. Rozliczenia wykazywane w deklaracjach pozwalają określić kwotę podatku, którą należy uiścić do Urzędu Skarbowego bądź wielkość nadwyżki VAT naliczonego nad podatkiem należnym. Podstawowymi, składanymi regularnie formularzami dla podatku od wartości dodanej są VAT - 7 oraz VAT - 7K [Krywan 2016b: 20-21].

Ustawodawca daje podatnikom prawo do zadecydowania o kwocie nadwyżki VAT naliczonego nad VAT należnym. Do sposobów zadysponowania nadwyżką należą [Krywan 2016a: 183]: zwrot całości nadwyżki na rachunek bankowy podatnika, przeniesienie całości nadwyżki do rozliczenia w następnym okresie lub zwrot części nadwyżki na rachunek bankowy podatnika wraz z przeniesieniem pozostałej części do rozliczenia w kolejnym okresie. Podatnik może się spodziewać zwrotu przysługującej mu nadwyżki w ciągu 60 dni, licząc od dnia złożenia w US właściwej deklaracji [Art. 87 ust.1 pkt 2 ustawy z dnia 11 marca 2004 r..., Dz.U. 2004, nr 54, poz. 535, z późn. zm.].

\section{SPECYFIKA ROZLICZEŃ KRAJOWYCH W PODATKU OD TOWARÓW I USŁUG DLA FIRM TRANSPORTOWYCH}

Zgodnie z artykułem 5 ustawy o VAT jednym z przedmiotów opodatkowanych podatkiem od wartości dodanej jest odpłatne świadczenie usług [Art. 5 ust. 1 ustawy z dnia 11 marca 2004 r..., Dz.U. 2004, nr 54, poz. 535, z późn. zm.]. Do tej grupy zaliczamy m.in. usługi transportu drogowego towarów. Świadczenie usług tego typu podlega bezwzględnie opodatkowaniu VAT.

Biorąc pod uwagę kwestię terytorialności VAT, świadczenie wszelkich usług drogowego transportu towarów w Polsce, których miejscem rozpoczęcia 
i zakończenia świadczenia usługi jest terytorium Rzeczpospolitej Polskiej, opodatkowane są również w Polsce.

Ustalenie podstawy opodatkowania podatkiem od towarów i usług z tytułu świadczenia usług krajowego transportu drogowego towarów nie różni się od sposobu, w jakim ustala się podstawę do opodatkowania VAT-em pozostałych towarów czy usług. Dokładna definicja podstawy opodatkowania podatkiem od wartości dodanej została zawarta w artykule 29a ust.1 ustawy o VAT [Art. 29a ust. 1 ustawy z dnia 11 marca 2004 r..., Dz.U. 2004, nr 54, poz. 535, z późn. zm.].

Ustalenie odpowiedniej stawki VAT dla drogowych usług transportowych świadczonych na terytorium Rzeczpospolitej Polskiej nie budzi żadnych wątpliwości. Usługi takie objęte są podstawową stawką VAT - 23\% [Olchowicz i in. 2015: 166].

Zakres podmiotowy w zakresie opodatkowania VAT w przypadku krajowego transportu drogowego towarów zgodny jest z zasadami ogólnymi zawartymi w art.15 ust.1 ustawy o VAT.

W przypadku świadczenia krajowych usług transportu drogowego, ustalenie momentu powstania obowiązku podatkowego VAT dokonuje się zgodnie z zasadami ogólnymi i szczególnymi określonymi w przepisach prawa. Ustalenie chwili, w której usługa transportowa może zostać uznana za wykonaną, należy do obowiązku stron biorących udział w transakcji.

Stroną transakcji, która jest odpowiedzialna za wywiązanie się z obowiązku podatkowego jest podmiot świadczący usługę transportu drogowego towarów, czyli firma transportowa [Zubrzycki 2015: 322]. Zasadniczo obowiązek podatkowy musi zostać uregulowany przez sprzedawcę usług wraz z upływem ostatniego dnia miesiąca bądź kwartału, kiedy dana usługa transportowa została wykonana [Zubrzycki 2015: 323].

Dla celów rozliczenia się z urzędem skarbowym niezbędne jest posiadanie wszystkich faktur poświadczających zakup bądź sprzedaż usługi transportowej. To w nich zawarte są najważniejsze dane dotyczące transakcji, czyli stawka oraz wysokość VAT. Polski ustawodawca w artykule 106i ust. 1-2 ustawy o VAT określił ogólnie obowiązujące warunki oraz zasady wystawiania faktur VAT, które dotyczą także świadczenia usług transportowych [Art. 106i ust. 1 i 2 ustawy z dnia 11 marca 2004 r..., Dz.U. 2004, nr 54, poz. 535, z późn. zm.]. Obowiązkiem usługodawcy jest wystawienie faktury nie później niż do 15. dnia miesiąca występującego po miesiącu, w którym miało miejsce świadczenie usługi [Zubrzycki 2015: 322]. Zakazane jest wystawianie faktur dotyczących świadczenia usług transportowych w terminie wcześniejszym niż 30 dni przed otrzymaniem całości bądź części należności (przed wykonaniem usługi) oraz wcześniej niż 30 dni przed wykonaniem danej usługi [Zubrzycki 2015: 323]. 
Podmioty wykonujące odpłatne świadczenie usług transportu drogowego, obowiązane są do prowadzenia stosownych ewidencji VAT w celu sporządzania prawidłowych zeznań podatkowych zgodnie $\mathrm{z}$ art. 109 oraz art. 110. Zasady odliczania podatku naliczonego VAT oraz zasady zwrotu jego nadpłaty, w przypadku świadczenia krajowych usług zawarte zostały w ustawie o VAT. Ustawodawca nie zawarł w przepisach ustawy żadnych wyjątków dotyczących świadczenia usług na terytorium Polski, dlatego też podatnik chcący skorzystać z prawa do obniżenia VAT należnego oraz zwrotu nadwyżki VAT naliczonego powinien odnieść i stosować się do przepisów ogólnych.

\section{IDENTYFIKACJA CZYNNIKÓW WPŁYWAJĄCYCH NA ROZLICZENIE KRAJOWYCH TRANSAKCJI W PODATKU OD WARTOŚCI DODANEJ NA PRZYKŁADZIE FIRMY TRANSPORTOWEJ XXX}

Badania prowadzące do identyfikacji czynników wpływających na prawidłowość rozliczeń krajowych transportu towarów w podatku od wartości dodanej zostały przeprowadzone w Firmie Transportowej XXX. Użyto fikcyjnej nazwy przedsiębiorstwa w celu ochrony danych dotyczących jednostki. Analizie poddane zostały faktury VAT sprzedaży wystawione przez badany podmiot, potwierdzające świadczenie usług transportu drogowego towarów. W celu dokładnego pokazania sposobu rozliczenia z VAT w firmie transportowej stworzono hipotetyczne faktury VAT zakupów, ewidencje VAT oraz deklaracje, które jednostka powinna złożyć do właściwego urzędu skarbowego. Do zastosowanych metod badawczych należą analiza dokumentów oraz wywiad swobodny przeprowadzony z właścicielem przedsiębiorstwa XXX.

Sporządzona analiza obejmuje okres miesięczny - marzec 2017 roku.

\subsection{Rozliczenia krajowe w VAT na przekładzie firmy transportowej XXX}

Firma XXX jest podmiotem, posiadającym aktywny status na rynku krajowych usług transportowych w zakresie przewozu towarów. Działalność gospodarcza XXX obejmuje swym działaniem terytorium Polski. Wszelkie operacje gospodarcze mające miejsce w przedsiębiorstwie XXX są ewidencjonowane za pomocą Podatkowej Księgi Przychodów i Rozchodów (tzw. KPiR). Firma XXX jest czynnym płatnikiem VAT (tzw. VAT-owcem). Pierwszym obowiązkiem, z którego musiał wywiązać się właściciel XXX, aby stać się czynnym podatnikiem VAT było złożenie tzw. zgłoszenia rejestracyjnego, przy pomocy formularza VAT-R do naczelnika właściwego urzędu skarbowego. 
Badaniu zostaną poddane dokumenty zgromadzone przez Firmę XXX świadczącą usługi $\mathrm{w}$ zakresie krajowego transportu drogowego towarów. Wszelkie rozliczenia podatku od towarów i usług w Firmie Transportowej XXX odbywają się na podstawie faktur VAT sprzedaży usług oraz faktur VAT zakupu dóbr i usług. W celu zbadania sposobu rozliczeń w podatku od wartości dodanej w Firmie XXX użyję wystawionych przez nią dwóch faktur VAT sprzedaży oraz hipotetycznych faktur VAT zakupu, wystawionych w miesiącu marzec $2017 \mathrm{r}$. Jednostka, w ramach rozliczenia z podatku od wartości dodanej jest obowiązana do sporządzania ewidencji VAT (zawierającej rejestr VAT sprzedaży oraz rejestr VAT zakupu) oraz składania w terminach miesięcznych deklaracji VAT-7. Badania zostały przeprowadzone odrębnie dla transakcji sprzedażowych i zakupowych.

\subsubsection{ANALIZA TRANSAKCJI SPRZEDAŻOWYCH}

Jednym z czynników wpływających na poprawne rozliczenie podatku od towarów i usług jest ustalenie właściwej stawki VAT. Usługa transportu drogowego towarów świadczona na terytorium Polski objęta jest 23\% stawką VAT.

W celu ustalenia kolejnych czynników, mających wpływ na poprawność rozliczenia z VAT konieczne jest przeanalizowanie transakcji sprzedaży, które zaszły $\mathrm{w}$ badanym przedsiębiorstwie. Pierwsza $\mathrm{z}$ transakcji poddana badaniu dotyczyła świadczenia usługi transportowej na trasie Sochaczew-Zgierz, zaś kolejna usługa świadczona została na trasie Tychy-Kraków-Dąbrowa Tarnowska.

Pierwsza z transakcji sprzedaży usług w miesiącu marcu dotyczyła transportuna trasie Sochaczew-Zgierz. Usługa ta została potwierdzona wystawieniem przez XXX faktury VAT numer 13/3/2017. Dokument został sporządzony 10 marca 2017 r. Wystawiający fakturę zaznaczył na niej sposób płatności, jakim jest przelew w terminie do 24 kwietnia 2017 r. Bardzo ważnym elementem świadczenia usług transportowych jest wskazanie terminu dostawy, co pozwala na ustalenie momentu powstania obowiązku podatkowego. W przypadku faktury za usługę na trasie Sochaczew-Zgierz termin dostawy przypadał na 10 marca 2017 r., co wskazuje, że obowiązek podatkowy za świadczenie tej usługi powstał dokładnie tego samego dnia, czyli 10 marca. Świadczący daną usługę transportową oczekiwał w zamian otrzymanie wynagrodzenia o wartości brutto 492 zł, na którą składa się: 400 zł wartości netto za przewóz towarów oraz $23 \%$ VAT w kwocie 92 zl, stanowiący podatek należny dla firmy transportowej.

Następna, poddana badaniu transakcja dotyczyła transportu towarów na trasie Tychy-Kraków-Dąbrowa Tarnowska. Świadczenie tej usługi zostało potwierdzone fakturą $\mathrm{nr}$ 35/03/2017, wystawionej w dniu 17 marca 2017 roku. 
Obowiązek podatkowy za świadczenie tej usługi powstał dokładnie wraz z dniem 15 marca 2017 roku. Za wykonanie usługi transportowej, XXX oczekiwał od nabywcy wynagrodzenia w wysokości brutto 738 zł płatnego przelewem w terminie do 1 maja 2017 r. Wartość netto za usługę na trasie Tychy-Kraków -Sochaczew wynosiła 600 zł, zaś należny VAT od tej kwoty wyniósł 138 zł.

Kolejnym elementem wpływającym na rozliczenie w prawidłowy sposób podatku od towarów i usług jest ustalenie miejsca świadczenia usług, a co za tym idzie - miejsca opodatkowania zaistniałych transakcji. Każda z faktur dotyczyła świadczenia usług wyłącznie na terytorium Rzeczpospolitej Polskiej, zatem opodatkowane są w Polsce, zgodnie z obowiązującymi przepisami prawa.

Nie jest możliwe ustalenie wysokości podatku należnego VAT, gdy nie została ustalona właściwa podstawa opodatkowania. Podstawę opodatkowania w miesiącu marzec Firma XXX może obliczyć, jako sumę wartości netto z wszystkich wystawionych faktur VAT sprzedaży:

$$
400 \mathrm{zł}+600 \mathrm{zł}=1000 \mathrm{zł}
$$

Podstawa opodatkowania dotycząca świadczonych usług transportowych przez XXX wyniosła w miesiącu marcu 1000 zł. Znając już podstawę opodatkowania oraz stawkę, jaka obejmuje świadczenie krajowych usług transportu drogowego towarów możemy ustalić wysokość podatku należnego. Obliczenie podatku należnego we właściwy sposób determinuje prawidłowe rozliczenie z VAT. Obliczenia VAT należnego możemy dokonać dwojako. Pierwszym ze sposobów wyliczenia VAT należnego jest pomnożenie podstawy opodatkowania przez właściwą stawkę VAT, co powinno wyglądać następująco:

$$
1000 \mathrm{zl} * 23 \%=230,00 \mathrm{zł}
$$

Drugim ze sposobów wyliczenia wielkości VAT należnego do zapłaty w urzędzie skarbowym jest zsumowanie wyliczonych kwot podatku z faktur VAT sprzedaży. Obliczenie podatku należnego w Firmie XXX drugim sposobem powinno wyglądać następująco:

$$
92 \mathrm{zł}+138 \mathrm{zl}=230,00 \mathrm{zł}
$$

Przeprowadzone obliczenia wskazują, że podatek należny za miesiąc marzec, do zapłaty we właściwym urzędzie skarbowym w Firmie XXX wynosi $230,00 \mathrm{zł}$. 


\subsubsection{ANALIZA TRANSAKCII ZAKUPOWYCH}

Badana jednostka nie udzieliła dokładnych informacji dotyczących podatku naliczonego. W celu ustalenia czynników związanych z podatkiem naliczonym wpływających na rozliczenie VAT przyjęto hipotetyczne transakcje. Założono, że Firma XXX dokonywała w miesiącu marcu 2017 r. zakupów, które dały jej $\mathrm{z}$ tego tytułu prawo do odliczenia podatku naliczonego. Dotyczyły one kolejno: zakupu paliwa do samochodów ciężarowych oraz przejazdu samochodami ciężarowymi po płatnych drogach krajowych.

Pierwszą z analizowanych transakcji jest zakup paliwa do samochodów ciężarowych. Otrzymana w związku z tą transakcją faktura zbiorcza została wystawiona 31 marca 2017 r. Paliwo opodatkowane jest 23\% stawką VAT, co zostało zaznaczone $\mathrm{w}$ otrzymanym dokumencie. Wartość netto za zakup paliwa w miesiącu marcu 2017 r. wynosiła 7 150,00 zł, kwota VAT 1 644,50 zł, zaś wartość brutto $8794,50 \mathrm{zł}$.

Następnie poddano analizie nabytą usługę przejazdu samochodami ciężarowymi po płatnych drogach krajowych. Otrzymana w związku z tą transakcją faktura zbiorcza została wystawiona 31 marca 2017 r. Otrzymana faktura VAT zakupu dostarcza wszystkich niezbędnych informacji potrzebnych do rozliczenia podatku od wartości dodanej $\mathrm{w}$ związku $\mathrm{z}$ tą transakcją. Przejazd po drogach krajowych opodatkowany został stawką podstawową VAT - 23\%. Wartość netto za przejazd drogami krajowymi w miesiącu marcu 2017 r. wynosi 2 100,00 zł, kwota VAT 483,00 zł, zaś wartość brutto 2 583,00 zł.

W przypadku dokonywania zakupów, dających Firmie XXX prawo do odliczenia podatku naliczonego, ważnym czynnikiem jest prawidłowe obliczenie wysokości, zapłaconego przy dokonywanych zakupach, podatku naliczonego. Na podstawie powyższych danych dotyczących wykonanych zakupów Firmy XXX możemy obliczyć łączną wartość podatku naliczonego, sumując wartości podatku z faktur:

$$
1644,50 \mathrm{zł}+483,00 \mathrm{zł}=2127,50 \mathrm{zł}
$$

Wielkość podatku naliczonego obliczymy również jako iloczyn sumy wartości netto z faktur zakupowych i odpowiadającej im stawki VAT:

$$
(7150 \mathrm{zl}+2100 \mathrm{zl}) * 23 \%=9250,00 \mathrm{zl} * 23 \%=2127,50 \mathrm{zl}
$$




\subsubsection{PRZEDSTAWIENIE SZCZEGÓLNYCH CZYNNIKÓW WPŁYWAJĄCYCH NA ROZLICZENIE PODATKU OD WARTOŚCI DODANEJ W FIRMIE TRANSPORTOWEJ XXX}

Wszystkie transakcje podlegające opodatkowaniu VAT powinny zostać odnotowane zarówno w ewidencji VAT sprzedaży, jak i ewidencji VAT zakupu. Regularne i zgodne z rzeczywistością prowadzenie ewidencji VAT determinuje prawidłowość w rozliczeniu podatku od wartości dodanej za dany okres.

Kolejnym etapem w prawidłowym rozliczeniu Firmy Transportowej z podatku od wartości dodanej jest ustalenie, czy za miesiąc marzec powstało zobowiązanie podatkowe, które skutkować będzie zapłatą nadwyżki VAT należnego nad naliczonym do właściwego urzędu skarbowego, czy też powstanie nadpłata VAT. W tym celu należy odjąć wielkość podatku naliczonego z faktur zakupu od podatku należnego z faktur sprzedaży w następujący sposób:

$$
230,00 \mathrm{zł}-2127,50 \mathrm{zł}=-1897,50 \mathrm{zł}
$$

Ujemny wynik informuje nas o powstaniu nadwyżki podatku naliczonego nad VAT należnym. W takim przypadku, za miesiąc marzec 2017 r. powstała nadpłata w wysokości 1897,50 zł, która powinna zostać Firmie XXX zwrócona. W Firmie XXX nie powstało zobowiązanie podatkowe za miesiąc marzec.

Ważnym czynnikiem przy rozliczaniu z VAT jest wybranie metody rozliczania $\mathrm{z}$ tego właśnie podatku. Właściciel przedsiębiorstwa transportowego XXX na samym początku prowadzenia działalności zdecydował na stosowanie miesięcznej metody rozliczania z VAT, zwanej również rozliczaniem na zasadach ogólnych. W związku z tym podatnik musi rozliczać wszelkie czynności prowadzące do powstania obowiązku podatkowego w terminach miesięcznych. W związku z decyzją o rozliczaniu się z VAT na zasadach ogólnych Firma XXX jest obowiązana do składania co miesiąc deklaracji VAT-7. Dokładny termin składania formularza VAT-7 upływa wraz z 25 dniem miesiąca, następującego po miesiącu, w którym obowiązek podatkowy z tytułu podatku od towarów i usług powstał. W badanym przypadku, Firma XXX jest obowiązana do złożenia w terminie do 25 kwietnia 2017 r. deklaracji VAT-7 uwzględniając na niej wielkości podatku należnego i naliczonego z faktur za miesiąc marzec $2017 \mathrm{r}$. Podatnik wypełniając formularz VAT-7 powinien na samym wstępie uzupełnić dane Firmy XXX oraz miesiąc i rok, którego dotyczy wypełniana deklaracja. Następnie, zgodnie z mającymi miejsce w marcu 2017 r. transakcjami zakupowymi i sprzedażowymi powinien uzupełnić formularz (rysunek 1).

Prawidłowe wypełnienie zeznania VAT-7 utwierdza nas, że z tytułu transakcji opodatkowanych VAT doszło do wystąpienia nadpłaty VAT naliczonego nad VAT należnym. Podatnik zdecydował, aby całość nadpłaty VAT została mu zwrócona na rachunek bankowy Firmy XXX. Takim sposobem, płatnik w ciągu 
60 dni, liczonych od momentu złożenia formularza VAT-7 do właściwego urzędu skarbowego, może spodziewać się zwrotu na rachunek bieżący przysługującej mu nadwyżki VAT.
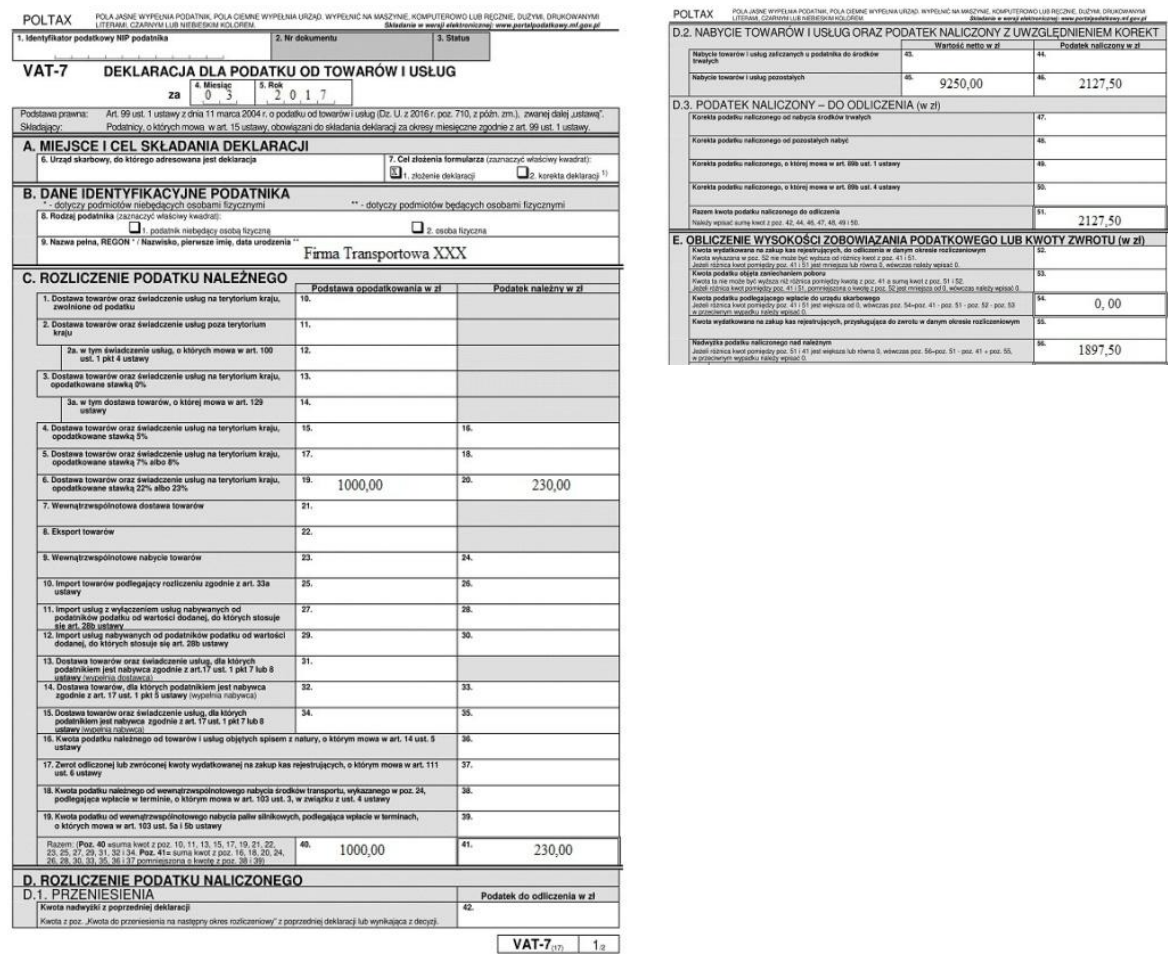

Rysunek 1. Deklaracja VAT-7 Firmy Transportowej XXX za miesiąc marzec 2017 r. - strona 1 , strona 2

Źródło: opracowanie własne.

\section{PODSUMOWANIE}

Prawidłowe rozliczenie z podatku od towarów i usług w firmach świadczących usługi transportu drogowego towarów zależy od wielu czynników. Jak pokazało przeprowadzone badanie, na rozliczenie z VAT w firmach transportowych świadczących usługi krajowe wpływa wiele różnorodnych czynników. Ich znajomość pozwoli jednostkom na prawidłowe i bezbłędne rozliczenie z VAT. Wykaz czynników wpływających na prawidłowe rozliczenie podatku od towarów i usług w przypadku transportu krajowego zostało przedstawione poniżej w tab. 1 . 
Rozliczenie z podatku od wartości dodanej jedynie na pozór sprawia wrażenie skomplikowanego. Należy jednak zapoznać się ze wszystkimi czynnikami wpływającymi na prawidłowe rozliczenie, aby zrozumieć istotę podatku od wartości dodanej i sposób jego funkcjonowania w polskim systemie podatkowym. Chęć samodzielnego rozliczania z VAT wiąże się z koniecznością ciągłego śledzenia wszelkich zmian przepisów podatkowych oraz regulacji.

Tabela 1. Czynniki wpływające na prawidłowe rozliczenie podatku od towarów i usług w przypadku

\begin{tabular}{|c|c|}
\hline & $\begin{array}{c}\text { Transport krajowy- Firma } \\
\text { transportowa XXX }\end{array}$ \\
\hline Usługodawca & Polski podatnik \\
\hline Usługobiorca & Podatnik z Polski \\
\hline Rejestracja VAT UE & Nie dotyczy \\
\hline $\begin{array}{c}\text { Dokumentacja świadczonych } \\
\text { usług }\end{array}$ & $\begin{array}{c}\text { Faktury VAT, Miedzynarodowe } \\
\text { Listy Przewozowe CMR }\end{array}$ \\
\hline Termin fakturowania & $\begin{array}{c}\text { Do } 15 \text {. dnia miesiąca } \\
\text { nastẹpującego po miesiącu, } w \\
\text { którym powstal obowiązek } \\
\text { podatkowy }\end{array}$ \\
\hline $\begin{array}{c}\text { Ewidencjonowanie transakcji } \\
\text { VAT }\end{array}$ & $\begin{array}{c}\text { Tak- prowadzenie ewidencji VAT } \\
\text { sprzedaży oraz ewidencji VAT } \\
\text { zakupu }\end{array}$ \\
\hline Przedmiot opodatkowania & Śviadczenie usług transportowych \\
\hline Miejsce świadczenia usług & Terytorium Polski \\
\hline Miejsce opodatkowania usług & Polska \\
\hline $\begin{array}{l}\text { Moment powstania } \\
\text { obowiazku podatkowego }\end{array}$ & $\begin{array}{c}\text { Dzień rozładunku towaru- data } \\
\text { dostawy na fakturach VAT } \\
\text { sprzedaży }\end{array}$ \\
\hline Podstawa opodatkowania & $\begin{array}{c}\text { Suma wartości netto } \mathrm{z} \text { faktur VAT } \\
\text { sprzedaży usług }\end{array}$ \\
\hline $\begin{array}{l}\text { Przeliczanie faktur } \\
\text { walutowych na polskie złote }\end{array}$ & Nie dotyczy \\
\hline Stawka VAT & Stawka podstawowa- $23 \%$ \\
\hline Podatek należny & $\begin{array}{c}\text { Tak- wysokość podatku } \\
\text { należnego obliczana jako iloczyn } \\
\text { podstawy opodatkowania oraz } \\
\text { stawki VAT } 23 \%\end{array}$ \\
\hline $\begin{array}{c}\text { Prawo do odliczenia podatku } \\
\text { naliczonego }\end{array}$ & $\begin{array}{c}\text { Przysługuje (za nabyte towary/ } \\
\text { usługi na terytorium Polski, } \\
\text { związane z prowadzona } \\
\text { działalnościa gospodarcza) }\end{array}$ \\
\hline Podatek naliczony & $\begin{array}{c}\text { Wysokość podatku naliczonego } \\
\text { obliczana jako sume iloczynów } \\
\text { łącznej wartości netto z wszystkich } \\
\text { faktur VAT zakupu oraz } \\
\text { odpowiadają̧cych im stawek VAT }\end{array}$ \\
\hline Zobowiązanie podatkowe & $\begin{array}{l}\text { Może powstać, gdy podatek } \\
\text { należny bẹdzie wiêkszy od } \\
\text { podatku naliczonego }\end{array}$ \\
\hline Deklaracje & $\begin{array}{c}\text { Dla celów rozliczenia podatku od } \\
\text { towarów i usług naleźy } \\
\text { prawidłowo wypełnić deklaracje } \\
\text { VAT- } 7 \text { do } 25 \text {. dnia miesiąca } \\
\text { nastepującego po miesiącu, w } \\
\text { którym obowiązek podatkowy } \\
\text { powstał }\end{array}$ \\
\hline
\end{tabular}

Źródło: opracowanie własne. 


\title{
BIBLIOGRAFIA
}

Dyszy W., 2014, Transport - opodatkowanie transportu i spedycji 2014, Forum Doradców Podatkowych, Kraków 2014.

Kostrzycka B., http://poradnikprzedsiebiorcy.pl/-odwrotne-obciazenie-a-sprzedaz-zakupionychtowarow [dostęp: 14.12.2016]

Krywan T., Jak rozliczyć VAT od importu ustug, https://rip.rachunkowosc.com.pl/jak_rozliczyc_ vat_od_importu_uslug.

Krywan T., 2016a, VAT 2016 cz. 1, „Dziennik Gazeta Prawna”, Warszawa.

Krywan T., 2016b, VAT 2016 cz. 2, „Dziennik Gazeta Prawna”, Warszawa.

Krywan T., 2016c, VAT rozliczenia w praktyce, „Dziennik Gazeta Prawna”, Warszawa.

Lazarowicz A., http://poradnikprzedsiebiorcy.pl/-rejestr-sprzedazy-i-zakupu-vat [dostęp: 19.12.2016]

Olchowicz I., Felis P., Jamroży M., Szlęzak- Matusewicz J., 2015, VAT w działalności gospodar$c z e j$, Difin SA, Warszawa.

Sowa B., 2014, Przedsiębiorstwo jako podatnik podatku od towarów i ustug (VAT), „Modern Mangament Review”, vol. XIX, 21 (1/2014), http://doi.prz.edu.pl/pl/pdf/zim/107 [dostep: 10.12.2016].

Szwęch A., http://ksiegowosc.infor.pl/poradniki/1395,6,Jak-wybrac-metode-rozliczania-VAT.html [dostęp: 16.12.2016].

Thuronyi V., 1996, Tax Law Design and Drafting. Value-Added Tax, „International Monetary Fund", vol. 1,

Ustawa z dnia 11 marca 2004 r. o podatku od towarów i usług, Dz.U. 2004, nr 54, poz. 535, z późn. zm.

Ustawa z dnia 8 stycznia 1993 r. o podatku od towarów i usług oraz o podatku akcyzowym, Dz.U. 1993, nr 11, poz. 50 z późn.. zm.

Wyrok Naczelnego Sądu Administracyjnego z 24 kwietnia 2007 r., sygn. akt I FSK 603/06.

Zubrzycki J., 2015, Leksykon VAT 2015, tom 2, Oficyna Wydawnicza UNIMEX, Wrocław.

[www1] http://www.finanse.mf.gov.pl/pp/niezbednik-podatnika/vat [dostęp: 12.12.2016]

[www2] Nowa dyrektywa VAT (1) - Naczelne zasady systemu podatku VAT $w$ VI dyrektywie i nowej dyrektywie VAT, http://www.podatki.biz/artykuly/8_74.htm [dostęp: 05.12.2016]

[www3] Podatki, http://serwisfinansowy.net [dostęp: 05.12.2016]

\section{FACTORS INFLUENCING THE SETTLEMENT OF DOMESTIC TRANSACTIONS IN VALUE ADDED TAX IN TRANSPORT COMPANIES}

\begin{abstract}
This article was written in connection with many problems of taxpayers with the correct settlement of value added tax. These problems result, among other things, from the frequent changes in tax regulations, the continuous development of the transport industry in Poland and the expansion into foreign markets.

The aim of the thesis is to identify the factors influencing the correctness of domestic settlements in value added tax for transport companies. The publication discusses the structural elements of the goods and services tax in Poland, characterizes the specificity of domestic settlements in VAT for transport companies and presents the procedure of domestic settlements
\end{abstract}


in value added tax on the example of Transport Company XXX. The studies were carried out on the basis of the relevant documentation of all VAT transactions that took place in the above mentioned company in March 2017. The conducted research revealed a multitude of factors affecting the correct settlement of goods and services tax in companies providing domestic transport services. Their knowledge and proper application has a very large impact to correctly settle accounts with the Tax Office and keep tax books in accordance with the law

Keywords: transport, input VAT, output VAT. 